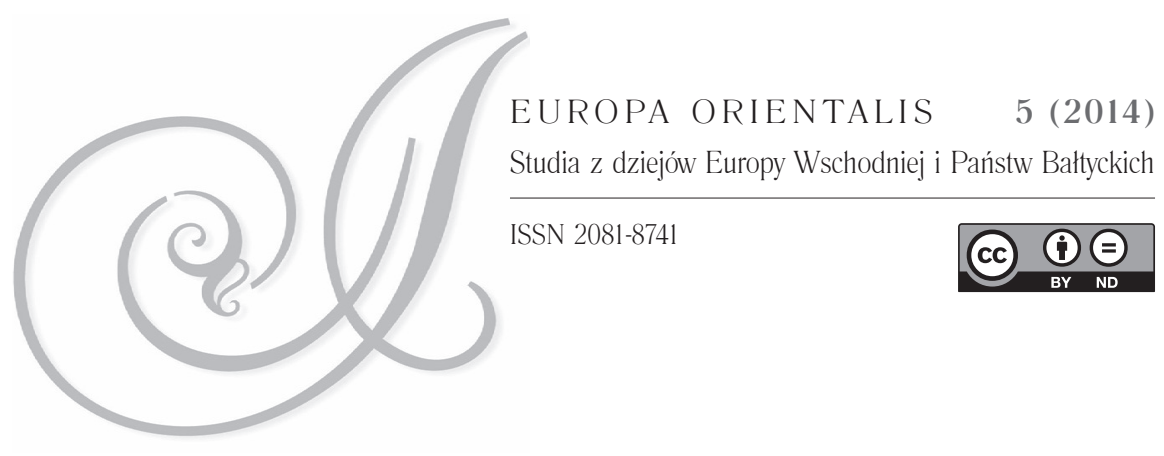

DOI: http://dx.doi.org/10.12775/EO.2014.012

\title{
„Cytadela” - nowy ukraiński periodyk poświęcony historii wojskowej. Omówienie tomów od 5 do 7 za lata 2011-2012*
}

$\mathrm{T}$

om 1 z 2011 r., czyli inaczej 5, „Cytadeli” obejmujący w sumie 8 opracowań ${ }^{1}$ otwiera dział „Historia wojskowa”, w którym znalazł się dość obszerny tekst Jurija Mocznikowa dotyczący kampanii galicyjskiej 1809 r. $^{2}$ Jest to kontynuacja rozważań autora, które ukazały się w tomach 3 i 4 ,Cytadeli” w 2010 r. ${ }^{3}$ Podobnie jak poprzednio, powstał on w oparciu o podstawową literaturę przedmiotu, wyłącznie polskojęzyczną, oraz nieliczne publikowane źródła relacyjne - tak przynajmniej wynika z zamieszczonych przez Jurija Mocznikowa przypisów źródłowych. Tym razem autor omówił przebieg działań Wojska Polskiego oraz korpusu austriackiego na terenie Księstwa Warszawskiego, które miały miejsce po bitwie pod Raszynem i zajęciu przez Austriaków Warszawy, a także wkroczenie pierwszych oddziałów polskich do Galicji wiosną 1809 r. oraz kwestię obecności na tym obszarze rosyjskiego Korpusu Pomocniczego gen. pie-

* Pierwsza część tego tekstu omawiająca numery od 1 do 4 „Cytadeli. Lwowskiego almanachu wojskowego" (Цитаделя. Львівський Мілітарний Альманах) za lata 2009-2010 ukazała się w 2013 r. w tomie 4 „Europa Orientalis” (s. 159-172).

1 Tom liczy w sumie 124 strony tekstu.

2 Ю. Мочніков, 1809. Битва за Галичину (продовжения), „Цитаделя. Львівський Мілітарний Альманах" 2011, частина 1 (5), s. 4-22.

3 Idem, 1809. Битва за Галичину (початок), „Цитаделя. Львівський Мілітарний Альманах" 2010, частина 1 (3), s. 4-20; idem, 1809. Битва за Галичину (продовжения), „Цитаделя. Львівський Мілітарний Альманах” 2010, частина 2 (4), s. 4-24. 
choty Siergieja Fiodorowicza księcia Golicyna ${ }^{4}$. W efekcie tekst ma raczej charakter popularnonaukowy i nie wnosi niczego nowego do wcześniejszej wiedzy o tych wydarzeniach, która dostępna jest chociażby w dotychczasowym dorobku polskiej historiografii - zarówno tej starszej, jak i nowszej.

Zdecydowanie istotniejszym tekstem $\mathrm{w}$ tym dziale jest publikacja rękopiśmiennego źródła omawiającego organizację i działanie wywiadu Ukraińskiej Armii Halickiej. Jest to opracowanie autorstwa Iwana Łemkiwskiego 5 . W rzeczywistości pod tym nazwiskiem kryje się czetar Iwan Wysłocki, który służył w Wydziale Wywiadowczym Komendy Naczelnej Ukraińskiej Armii Halickiej ${ }^{6}$. Przedstawił on trudne początki wywiadu Ukraińskiej Armii Halickiej, który rodził się niejako samoczynnie w wyniku konkretnych potrzeb tego typu istniejących na froncie, a także pierwsze próby nadania mu odpowiednich, wzorowanych na rozwiązaniach zaczerpniętych z armii austro-węgierskiej, struktur organizacyjnych, jakie podejmowano pomimo braku zrozumienia dla tych kwestii u wielu ówczesnych ukraińskich dowódców. Wbrew przeszkodom utworzono jednak Wydział Wywiadowczy przy Komendzie Naczelnej Ukraińskiej Armii Halickiej. Poza tym podobne komórki powstały również przy poszczególnych korpusach, a nawet w brygadach tej armii. W sumie jednak służyło w nich niewielu oficerów, gdyż ich liczba wynosiła nieco ponad 40 „dusz”.

Według autora tego dokumentu wywiad Ukraińskiej Armii Halickiej, oprócz kwestii czysto wojskowych, zajmował się także sprawami politycznymi, jak choćby organizacją zajęcia Lwowa przez Ukraińców 1 listopada 1918 r., a następnie utrwalaniem władzy cywilnych i wojskowych orga-

${ }^{4}$ Niestety, podobnie jak w przypadku pierwszej części swego opracowania, autor nie wykorzystał całego szeregu istotnych, wręcz fundamentalnych, opracowań polskojęzycznych, jak choćby monografii: M. Kukiel, Dzieje oręża polskiego w epoce napoleońskiej 1795-1815, Poznań 1912; B. Pawłowski, Wojna polsko-austriacka 1809 r., Warszawa 1999 (wyd. 1: Warszawa 1935); G. Zych, Armia Księstwa Warszawskiego 1807-1809, Warszawa 1961, a także biografii: A. M. Skałkowski, Książę Józef, Bytom 1913; J. Pachoński, Generat Jan Henryk Dąbrowski 1755-1818, Warszawa 1981; J. Skowronek, Ksiązę Józef Poniatowski, Wrocław-Warszawa-Kraków-Gdańsk-Łódź 1984.

5 І. Лемківський, Розвідка УГА. Організвція і праия Розвідочного Відділу Н.К.У.Г.А, „Цитаделя. Львівський Мілітарний Альманах” 2011, частина 1 (5), s. 23-32.

6 Zob. В. Кучерук, Українська Галищька Армія. Довідник, Львів 2010, s. 65. Warto też tutaj przypomnieć, iż oficer ten pozostawił po sobie bardzo ciekawe wspomnienia, w których przedstawił swoją służbę w wywiadzie Cesarsko-Królewskiej Armii Austro-Węgierskiej, w Strzelcach Siczowych armii Ukraińskiej Republiki Ludowej oraz działalność w szeregach Ukraińskiej Armii Halickiej - zob. I. Вислоцький, Спомини розвідчого старшини з Першої світової війни: Австрійська армія. Київські Січові Стрільці і Українська Галицька Армія, Львів 2005. 
nów Zachodnio-Ukraińskiej Republiki Ludowej oraz zwalczaniem, we współpracy z żandarmerią, ukraińskich komunistów. Ponadto autor omówił również poszczególne etapy w organizacji i rozwoju ukraińskiego wywiadu, w tym także niedostatki w działaniu wywiadu połączonych sił Armii Czynnej Ukraińskiej Republiki Ludowej oraz Ukraińskiej Armii Halickiej.

Z przedstawionym źródłem w bezpośredni sposób koresponduje tekst Ołeksandra Diedyka zawierający uwagi oraz uzupełnienia do jego treści ${ }^{7}$. Autor ten rozwiązuje bowiem, kto kryje się pod pseudonimem „Iwan Łemkiwski”, potwierdzając jednocześnie, iż jest to wspomniany wcześniej czetar Iwan Wysłocki. Poza tym Ołeksandr Diedyk przedstawił bogaty życiorys Wysłockiego. Jednocześnie podał nieco danych dotyczących organizacji oraz sposobu działania wywiadu wojskowego Ukraińskiej Armii Halickiej, aż do momentu jej odejścia za Zbrucz w lipcu 1919 r.

Dla potencjalnego polskiego czytelnika tego tekstu najistotniejsze mogą być informacje odnoszące się do ofensywy czortkowskiej przeprowadzonej przez Ukraińców w czerwcu tego roku ${ }^{8}$, a także działań 4 Dywizji Strzelców Polskich gen. ppor. Lucjana Żeligowskiego, jakie miały miejsce nad Dniestrem w końcu tego miesiąca. Zauważyć jednak należy, że wiadomości dotyczące walk 4 Dywizji Strzelców Polskich oraz kawalerii polskiej na tym obszarze nie wykraczają poza wcześniejsze podstawowe ustalenia literatury polskiej ${ }^{9}$. Nie stanowią one jednak głównego wątku jego

7 О. Дєдик, Трилогія розвідника. Нотатки до публікаиії рукопису Івана Лемківського „Розвідка УГА. Організвція і прачя Розвідочного Відділу НК УГА”, „Цитаделя. Львівський Мілітарний Альманах” 2011, частина 1 (5), s. 33-41.

${ }^{8}$ Szerzej zob.: M. Klimecki, Czortków 1919, Warszawa 2000; О. Дєдик, Чортківська офензива. Частина I, Львів 2013. Tа ostatnia praca jest najnowszym i najkompletniejszym osiągnięciem współczesnej historiografii ukraińskiej.

9 Obszerniej zob. choćby: W. Hupert, Zajęcie Małopolski Wschodniej i Wolynia w roku 1919, Lwów-Warszawa 1928; A. Przybylski, Wojna polska 1918-1921, Warszawa 1930; H. Kiszko-Zgierski, Zarys historii wojennej 6-go Pułku Ułanów Kaniowskich, Warszawa 1930; A. Hlawaty, Dzieje 6 Pułku Ułanów Kaniowskich, Londyn 1973; M. Kozłowski, Między Sanem a Zbruczem. Walki o Lwów i Galicję Wschodnia 1918-1919, Kraków 1990, idem, Zapomniana wojna. Walki o Lwów i Galicję Wschodnia 1918-1919, Bydgoszcz 1999; M. Wrzosek, Wojny o granice Polski Odrodzonej 1918-1921, Warszawa 1992; G. Łukomski, Cz. Partacz, B. Polak, Wojna polsko-ukraińska 1918-1919. Działania bojowe-aspekty polityczne - kalendarium, Koszalin-Warszawa 1994; A. Smoliński, Powrót do kraju oddziałów jazdy sformowanych w ramach 4 Dywizji Strzelców Polskich oraz ich właczenie w sktad Wojska Polskiego - 1919 r., „Przegląd Kawalerii i Broni Pancernej” 1999, t. 25, Nr 158; idem, Marsz z Rumunii do Polski oddziałów jazdy utworzonych w ramach 4 Dywizji Strzelców Polskich oraz ich właczenie do struktur Wojska Polskiego - 1919 rok, [w:] Relacje polsko-rumuńskie w historii i kulturze. Materiaty z sympozjum. (Relaţii polono-romăne în istorie şi cultură. Materialele simpozionului), red. S. Iachimovschi, E. Wie- 
rozważań, co mogło być istotną przyczyną jedynie takiego pobieżnego ich potraktowania. Wartość tego tekstu podnosi natomiast fakt, iż poza podstawową polsko- i ukraińskojęzyczną literaturą przedmiotu autor wykorzystał również nieznane polskim historykom dokumenty archiwalne ukraińskiej proweniencji.

Kolejny tekst autorstwa Andrija Sowy zamieszczony w dziale „Dokument” dotyczy przebiegu kolektywizacji, która miała miejsce w okolicach Skolego ${ }^{10} \mathrm{w} 1948 \mathrm{r}$. oraz dotyczących tych wydarzeń źródeł relacyjnych ${ }^{11}$. Autor omawia w nim opór ludności chłopskiej przeciwko akcji kolektywizacyjnej przeprowadzanej przez władze sowieckie po 1945 r., który organizacyjnie i zbrojnie wspierany był przez oddziały UPA oraz OUN. Poza tym wskazuje on na zależność pomiędzy przymusową kolektywizacją a trwaniem i rozwojem na Zachodniej Ukrainie sił antysowieckiego ukraińskiego podziemia. Tekst ten oparty został na bogatej ukraińskojęzycznej literaturze przedmiotu oraz na kwerendzie archiwalnej w archiwach ukraińskiej służby bezpieczeństwa. Wzbogacają go ponadto dobrze dobrane i ciekawe reprodukcje ulotek oraz plakatów kolportowanych przez OUN i UPA w ramach propagandowej walki z akcją kołchozową. Oprócz tego autor jako załączniki do swego opracowania zamieścił także teksty odezw ukraińskiego podziemia kierowanych do ludności wiejskiej, a także fragment wspomnień jednego z jego uczestników ${ }^{12}$.

Następne opracowanie autorstwa Jarosława Tynczenki zaliczone zostało do działu „Biografistyka”. Dotyczy ono bowiem pewnych szczególnych momentów barwnej biografii znanego oficera Ukraińskiej Armii Halickiej,

ruszewska-Calistru, Suceava 2010; R. Galuba, ,Niech nas rozsadzi miecz i krew...” Konflikt o Galicję Wschodnia w latach 1918-1919, Poznań 2004.

${ }^{10}$ Czyli na Bojkowszczyźnie, która o czym warto pamiętać, była obszarem dość specyficznym zarówno pod względem typu chłopskiej gospodarki, jak i pozostałych elementów kultury materialnej i duchowej. Fakty te zapewne miały wpływ na przebieg omawianych w tym tekście wydarzeń - szerzej zob.: Р. Кирчів, Із фольклорних регіонів Украӥни. Нариси й статmi, Львів 2002; A. Karczmarzewski, Świat Bojków. Etnograficzna podróż po Bojkowszczyźnie, Rzeszów 2014.

11 А. Сова, Маловідомі спогади про опір украӥнського збройного підпілля колективізайї на Сколівщині у 1948 роиі, „Цитаделя. Львівський Мілітарний Альманах" 2011, частина 1 (5), s. 42-57.

${ }_{12} \mathrm{Na}$ marginesie tego tekstu warto też przypomnieć, iż opór sowieckim działaniom kolektywizacyjnym na Ukrainie stawiały także wsie zamieszkałe przez resztki ludności polskiej, która pozostała tam mimo powojennej akcji wysiedleńczej niesłusznie zwanej ,repatriacją" - szerzej zob. Głód i represje wobec ludności polskiej na Ukrainie 1932-1947. Relacje, red. R. Dzwonkowski, Lublin 2004. 
mianowicie Osypa Bukszowannego ${ }^{13}$, który w 1920 r. przeszedł na stronę Sowietów. W artykule tym autor omawia zawartość teczki archiwalnej, w której znajdują się gromadzone przez sowieckie organy bezpieczeństwa dokumenty związane z Bukszowannym dotyczące okresu jego pobytu i działalności w ZSRS. Warto też pamiętać, że jego karierę ostatecznie przerwało aresztowanie w $1933 \mathrm{r}$. w ramach sfabrykowanej sprawy tzw. ukraińskiej organizacji wojskowej, a następnie wyrok oraz śmierć w listopadzie 1937 r. w słynnym sowieckim łagrze na Sołowkach.

Dalszy tekst przygotowany przez Michajło Słobodianiuka należy do działu „Uniformistyka”. Tym razem autor ten zajął się dziejami oraz „barwą” Artylerii Konnej Gwardii Królewsko-Polskiej armii Królestwa Polskiego ${ }^{14}$. Jak zwykle osnową jego ustaleń poza podstawową literaturą, przede wszystkim polską, stały się przechowywane w zbiorach Lwowskiego Muzeum Historycznego obrazy olejne autorstwa Józefata Ignacego Łukaszewicza przedstawiające oficerów i szeregowych Baterii Pozycyjnej Artylerii Konnej Gwardii, które są wręcz bezcennymi źródłami do poznania „broni i barwy” ${ }^{15}$ Wojska Polskiego Królestwa Polskiego ${ }^{16}$.

Swój tekst rozpoczął autor od przedstawienia genealogii polskiej artylerii konnej, ale ku zaskoczeniu zorientowanego w temacie potencjalnego polskiego czytelnika jej początki umieścił w 1794 r. w ramach tzw. Korpusu Polskiego armii rosyjskiej, który niestety poza składem osobowym złożonym głównie z Polaków nie był Wojskiem Polskim, ani tym bardziej nie należy się mu pod tym względem pierwszeństwo. Pierwsze formacje artylerii tego typu, nawet jeżeli ostateczne rozstrzygnięcie tego zagadnienia uznamy za otwarte, próbowano bowiem tworzyć już w armii Rzeczypospolitej Obojga Narodów ${ }^{17}$. Dalej, tym razem słusznie, autor wspomina o artylerii

13 Я. Тинченко, Слідчі справи Осипа Букшованного, „Цитаделя. Львівський Мілітарний Альманах" 2011, частина 1 (5), s. 58-62. W swym niezwykle urozmaiconym życiu był on m.in. dowódcą 1 Brygady Ukraińskich Strzelców Siczowych II Korpusu Ukraińskiej Armii Halickiej - szerzej o tej barwnej postaci zob. В. Кучерук, op. cit., s. 61-62.

14 М. Слободянюк, Польська гвардійска кінна артилерія в живописі Юзефата Лукашевича зі збірки Львівського Історичного Музею, „Цитаделя. Львівський Мілітарний Альманах” 2011, частина 1 (5), s. 63-88.

15 Wydaje się, iż pod względem wartości źródłowej z obrazami Łukaszewicza porównywalne mogą być tylko znajdujące się w zbiorach Muzeum Wojska Polskiego w Warszawie akwarele Romana Rupniewskiego.

${ }^{16}$ A także części formacji armii rosyjskiej z tego okresu.

17 Zob.: K. Koźmiński, Artyleria konna, [w:] Księga jazdy polskiej, red. B. Wieniawa-Długoszowski, Warszawa 1938; Rodowody artylerii konnej Wojska Polskiego, red. J. Boguski, Londyn 1964; T. Ciesielski, Armia koronna w czasach Augusta III, Warszawa 2009; 
konnej Legii Naddunajskiej oraz obszernie opisuje dzieje artylerii konnej Wojska Polskiego Księstwa Warszawskiego. Czy taki zabieg był konieczny? Inaczej jest natomiast z kwestią baterii pozycyjnej oraz baterii lekkokonnych Wojska Polskiego z lat 1815-1831, choć i w tym przypadku potencjalny polski czytelnik nie dowie się raczej niczego nowego, czego nie byłby w stanie znaleźć we wcześniejszej polskiej literaturze historycznej ${ }^{18}$.

Oddzielny wątek rozważań Słobodianiuka dotyczy kwestii „barwy” Baterii Pozycyjnej Artylerii Gwardii Królewsko-Polskiej. Jednak objętościowo jest on znacznie uboższy od wspomnianej wcześniej części historyczno-organizacyjnej. Autor podał jednak najistotniejsze fakty związane z kształtem „barwy” tej formacji19. Wydaje się więc, iż dla potencjalnego polskiego czytelnika największą wartością tego tekstu jest publikacja związanych z artylerią konną gwardii obrazów autorstwa Józefata Łukaszewicza, do których obecnie badacze polscy mają utrudniony dostęp.

Następny tekst autorstwa Mykoły Czmyra należy do działu „Wojskowa symbolika", a dotyczy symboliki formacji Sił Powietrznych Ukrainy (Повітряні Сили України) ${ }^{20}$. Autor zajął się w nim procesem tworzenia oraz związanymi z tym problemami, a także perspektywami doty-

A. Smoliński, Proweniencja barw artylerii wojska Rzeczypospolitej Obojga Narodów w XVIII w., [w:] Artyleria polska. Historia - teraźniejszość - przyszłość (myśl wojskowa, szkolnictwo artyleryjskie, technika i uzbrojenie), materiały pokonferencyjne III konferencji naukowej Torun 11 maja 2009, sympozjum naukowe Toruń 4 grudnia 2009, Toruń 2010; idem, Mundur i barwy artylerii polskiej w XVIII i XIX wieku, Toruń 2010.

${ }^{18}$ Gwoli recenzenckiej rzetelności należy jednak zauważyć, że tekst ten powstał z myślą o czytelniku ukraińskim, a nie polskim, co w pewnym stopniu usprawiedliwia taką jego konstrukcję.

${ }_{19}$ Potencjalny polski czytelnik chcący zgłębić to zagadnienie może korzystać chociażby z licznych polskich drukowanych źródeł relacyjnych (zob. choćby: S. Jabłonowski, Wspomnienia o baterii artylerii konnej gwardii Królestwa Polskiego, Kraków 1860; J. Jaszowski, Pamiętnik dowódcy rakietników konnych, przedm. J. Łojek, Warszawa 1968) oraz z odpowiedniej i wartościowej polskiej literatury - zob. choćby: B. Gembarzewski, Żotnierz polski. Ubiór, uzbrojenie i oporzadzenie od wieku XI do roku 1965, t. 4: Od 1815 do 1831 roku, do druku przygot. Z. Stefańska, kolory plansz odtworzył K. Linder, Warszawa 1966; Z. Żygulski jun., H. Wielecki, Polski mundur wojskowy, Kraków 1988; A. Smoliński, Mundur i barwy artylerii polskiej w XVIII i XIX wieku; idem, Mundur i barwy artylerii konnej gwardii oraz artylerii lekkokonnej i rakietników konnych Wojska Polskiego Królestwa Polskiego w latach 1815-1830, [w:] Studia artyleryjskie red. M. Giętkowski, A. Smoliński, t. 3, Toruń 2012; J. Czop, Barwa armii Królestwa Polskiego 1815-1830 i 1831 (stare formacje), Rzeszów 2010. Cztery pierwsze wymienione tutaj opracowania zawierają także obszerny wykaz źródeł oraz dotyczącej tych kwestii literatury.

${ }_{20}$ М. Чмир, Симболіка військових частин Повітряних Сил України: становлення, проблеми, перспективи, „Цитаделя. Львівський Мілітарний Альманах” 2011, частина 1 (5), s. 89-112. 
czącymi kształtu symboliki wojskowej Sił Powietrznych współczesnych Sił Zbrojnych Ukrainy, a więc sztandarami, naramiennymi oznakami rozpoznawczymi i odznakami pamiątkowymi. Podkreślił też, iż system ten powstawał od przysłowiowego zera, a opracowali go fachowcy służący w Wojskowej Służbie Heraldycznej, która następnie przekształciła się w Oddział Symboliki Wojskowej i Heraldyki Sztabu Generalnego Sił Zbrojnych Ukrainy. Okoliczności te spowodowały, iż w symbolice tego rodzaju wojsk ukraińskiej armii nie wykorzystano praktycznie żadnych dosłownych rozwiązań graficznych nawiązujących do Robotniczo-Chłopskiej Armii Czerwonej, a następnie Armii Sowieckiej. Takie elementy nadal funkcjonują jednak w nazwach poszczególnych formacji, które dziedziczą tradycje swoich sowieckich antenatów. Atrakcyjność ustaleń zawartych w tym opracowaniu podnoszą liczne i dobrze dobrane barwne ilustracje pokazujące elementy omawianej przez autora symboliki. Poza tym został on zaopatrzony w liczne przypisy.

Omawiany tutaj tom zamykają rozważania Iriny Kmieć dotyczące pieśni Bogurodzica ${ }^{21}$. Należą one do działu „Muzyka wojskowa” niewystępującego wcześniej na łamach „Cytadeli”. Autorka podkreśliła, iż w polskiej kulturze ta religijna pieśń odgrywała niegdyś ważną rolę, przy czym uważana była także za pierwszy polski hymn ${ }^{22}$. Słusznie też zauważyła, że co najmniej od końca XIX w. stała się ona obiektem naukowych zainteresowań polskich ${ }^{23}$ i ukraińskich językoznawców ${ }^{24}$ oraz historyków i kulturologów ${ }^{25}$. Po raz kolejny obiektem jej rozważań stała się kwestia czasu powstania oraz pochodzenia tego utworu, w tym jego ewentualne czeskie bądź też nawet bizantyjskie korzenie. Jednocześnie autorka po raz kolejny powróciła do głoszonej na początku XX w. przez Wasylia Szczurata tezy

${ }_{21}$ Ibidem; I. Кметь, Пісня грюнвальдської перемохи: контроверсійність походження пам'ятки, „Цитаделя. Львівський Мілітарний Альманах” 2011, частина 1 (5), s. $113-122$.

${ }^{22}$ Szerzej o tych kwestiach zob. chociażby: S. Russocki, S. K. Kuczyński, J. Willaume, Godło, barwy i hymn Rzeczypospolitej. Zarys dziejów, Warszawa 1978.

${ }^{23}$ Zob.: A. Kalina, Rozbiór krytyczny pieści „Bogarodzica”, Lwów 1880; M. Bobowski, Polska poezja kościelna od najdawniejszych czasów aż do wieku XVI, Warszawa 1885; T. Kowalski, Pieśń „Bogarodzica” przypisywana św. Wojciechowi, Warszawa 1911, a także J. Stręciwilk, Bogurodzica, [hasło w:] Encyklopedia katolicka, t. 2, Lublin 1976, s. 722.

${ }_{24}$ Zob.: В. Щурат, Дві статї про грунвальлську пісню. Відповідь проф. Брікнерови, Жовква 1906; Б. Барвіньский, Bogurodzicza dziewicza a історичні висновки д-ра Щурата (в інтересі історичної правди), Львів 1906.

${ }_{25}$ Według ustaleń autorki w Polsce oraz na Ukrainie dotychczas ukazało się około 200 prac poświęconych Bogurodzicy, przy czym sporą część z nich można obecnie odnaleźć w sieci. 
o tym, iż Bogurodzica jest pamiątką „,zachodnioruskiej” twórczości religijnej z końca XIV w., a swoje związki z „ruską tradycją” zatraciła w efekcie późniejszych polskich transkrypcji i tym samym pewnych zmian o charakterze semantycznym. Przedstawiła i omówiła także krytyczną dyskusję, którą wywołała wówczas ogłoszona przez Szczurata praca, w tym także poglądy tych badaczy, jacy zaprzeczali głoszonym przez niego ustaleniom. Ostatecznie autorka nie rozstrzygnęła kwestii, z jakiej tradycji wywodzi się Bogurodzica - czy z łacińskiej (zachodniej), czy też z prawosławnej (wschodniej). Jednocześnie problem ten uznała za największą tajemnicę związaną z jej pochodzeniem i dalszymi dziejami, zaś jej wyjaśnienie może stać się zadaniem kolejnych pokoleń historyków ${ }^{26}$.

Kończąc omówienie tego tekstu, należy wyrazić żal, że znaczna część towarzyszących mu przypisów nie została wydrukowana, co w znaczący sposób utrudnia korzystanie z tego skądinąd ciekawego, również dla potencjalnego polskiego czytelnika, opracowania.

$\mathrm{Z}$ punktu widzenia zainteresowań polskiej historiografii w 5 tomie „Cytadeli” za najwartościowsze artykuły należy uznać tekst o „barwie” Baterii Pozycyjnej Artylerii Gwardii Królewsko-Polskiej oraz rozważania dotyczące „Bogurodzicy”.

Tom 2 za 2011 r., czyli inaczej 6, „Cytadeli” liczy w sumie 7 opracowań ${ }^{27}$. Otwiera go należący do działu „Historia wojskowa” tekst wspomnianego już wcześniej Jurija Mocznikowa dotyczący przebiegu kampanii galicyjskiej z 1809 r. ${ }^{28}$, który jest kontynuacją jego rozważań zamieszczonych $\mathrm{w}$ poprzednich tomach tego periodyku ${ }^{29}$. Tym razem autor zają1 się próbami przejęcia inicjatywny przez dowództwo austriackie w końcu maja i w czerwcu, a więc oblężeniem Sandomierza, walkami nad Wisłą i Pilicą, a także formowaniem w Galicji oddziałów galicyjsko-francuskich, czyli późniejszych pułków piechoty i jazdy Wojska Polskiego Księstwa

${ }^{26}$ W tekście tym brak jest jakichkolwiek oryginalnych ustaleń autorki, która praktycznie ograniczyła się jedynie do swoistego zreferowania kilku wcześniejszych poglądów naukowych dotyczących tej problematyki. Jej rozważania więc mają raczej charakter popularnonaukowy.

27 Tom liczy w sumie 116 stron tekstu.

28 Ю. Мочніков, 1809. Битва за Галичину (продовжения), „Цитаделя. Львівський Мілітарний Альманах" 2011, частина 2 (6), s. 4-19.

${ }^{29}$ Zob.: idem, 1809. Битва за Галичину (початок), „Цитаделя. Львівський Мілітарний Альманах” 2010, частина 1 (3), s. 4-20; idem, 1809. Битва за Галичину (продовжения), „Цитаделя. Львівський Мілітарний Альманах” 2010, частина 2 (4), s. 4-24; idem, 1809. Битва за Галичину (продовжения), „Цитаделя. Львівський Мілітарний Альманах" 2011, частина 1 (5), s. 4-22. 
Warszawskiego ${ }^{30}$. Tekst ten oparty został na podobnej do omówionej wcześniej podstawie źródłowej. Tak samo przedstawia się więc również jego wartość.

Znacznie wartościowszy i ciekawszy jest kolejny obszerny tekst zamieszczony w tym dziale. Jego autorem jest Czech Jiżi Płachy, który zajął się słabo opisaną kwestią mieszkańców Zakarpacia, głównie Ukraińców i „Rusinów”31, służących w latach 1944-1945 w szeregach walczącej na Zachodzie - pod francuskim portem Dunkierka - Samodzielnej Czechosłowackiej Brygady Pancernej, która już po zakończeniu wojny została rozbudowana i przekształcona w czterobrygadowy 1 Czechosłowacki Korpus Pancerny ${ }^{32}$. Poza omówieniem dziejów tej formacji na podstawie bogatej, przede wszystkim czeskiej, literatury przedmiotu oraz w oparciu o akta przechowywane w Wojskowym Archiwum Historycznym w Pradze ustalił on, w jakich formacjach czechosłowackich wojsk lądowych znajdowali się Ukraińcy i „Rusini” oraz jaki procent ich składu stanowili w końcowym okresie II wojny światowej ${ }^{33}$. Poza tym określił także, jakie były źródła ich rekrutacji. To ciekawe opracowanie uzupełniają załączniki zawierające podstawowe personalia oraz stopnie wojskowe i informacje o wyznaniu Ukraińców oraz „Rusinów” walczących pod Dunkierką w poszczególnych oddziałach czechosłowackiej brygady pancernej. Oprócz tego zamieszczono tam też dokładne ankiety personalne 32 żołnierzy ukraińskiej i „rusińskiej” narodowości.

Wydaje się, że ustalenia zawarte w tym tekście będą dla Ukraińców, a tym bardziej dla potencjalnego polskiego czytelnika, cennym uzupeł-

30 Szerzej na ten temat, poza częścią wcześniej cytowanej literatury, zob. także: B. Gembarzewski, Wojsko Polskie. Księstwo Warszawskie 1807-1814, Warszawa 1905; idem, Rodowody pułków polskich i oddziałów równorzędnych od r. 1717 do r. 1831, Warszawa 1925; M. Kukiel, Dzieje oręża polskiego w epoce napoleońskiej 1795-1815;Wojsko Księstwa Warszawskiego. Ułani, gwardie honorowe, pospolite ruszenie, żandarmeria konna, t. 1-2, Warszawa 2009 (tu rysunki A. Paczuskiego i R. Morawskiego); Wojsko Księstwa Warszawskiego. Piechota, gwardie narodowe, weterani, Warszawa 2014 (tu rysunki A. Paczuskiego i R. Morawskiego).

31 Taki podział stosuje autor tego opracowania.

32 Ї. Плахи, Вихідиі із Закарпаття в лавах Чехословацькой окремої бронетанкової бригади на фронті під Дюнкерком (1944-1945), „Цитаделя. Львівський Мілітарний Альманах" 2011, частина 2 (6), s. 20-54.

33 Według ustaleń Płachego na dzień 14 III 1945 r. w szeregach Samodzielnej Czechosłowackiej Brygady Pancernej służyło w sumie 53 Ukraińców i „Rusinów”, co stanowiło 0,92\% całości jej stanu osobowego wynoszącego wtenczas 5739 żołnierzy. 
nieniem dotychczasowej wiedzy o udziale Ukraińców w II wojnie światowej $^{34}$.

Następny tekst przygotowany przez Andrija Sowę umieszczony został w dziale „Dokument”. Jest to publikacja 3 dokumentów przechowywanych w Centralnym Państwowym Archiwum Historycznym Ukrainy we Lwowie, dotyczących działalności Dmytra Hrycaja w ukraińskim Towarzystwie Sokó1 ${ }^{35}$. Autor omówił w nim pokrótce cele istnienia oraz organizację Sokoła w powiecie samborskim, skąd pochodził Hrycaj, urodzony we wsi Dorożów. Publikowane dokumenty to pochodzące z lipca 1930 r. sprawozdanie podpisane przez Hrycaja i ojca Wasyla Szewczuka, który był wtenczas proboszczem w Dorożowie i wraz z nim kierował tamtejszym Sokołem. Dotyczy ono jego ówczesnej działalności. Poza tym jest to także pochodząca $\mathrm{z}$ tego samego czasu korespondencja pomiędzy lwowskim Sokołem-Batko a Sokołem w Samborze. Dla potencjalnego polskiego czytelnika ciekawe mogą być te wątki dokumentów, które świadczą o możliwości legalnego działania w II Rzeczypospolitej różnych organizacji ukraińskich, w tym wspomnianego Sokoła ${ }^{36}$.

W dziale „Uniformologia” Mychajło Słobodianiuk zamieścił kolejne ciekawe studium dotyczące „barwy”. Tym razem obiektem jego zainteresowań stał się rosyjski Podolski Pułk Kirasjerów Lejb Gwardii, który sformowany został w Warszawie w 1817 r. i stacjonował tam w latach 20. i 30. XIX w. ${ }^{37}$ Autor omówił jego dzieje, w tym udział w wojnie polsko-rosyjskiej 1831 r., oraz „barwę”, czyli umundurowanie i właściwe pułkowe barwy. Podobnie jak w poprzednio omawianych tekstach tego autora, również w tym przypadku swoje rozważania, poza podstawową literaturą przedmiotu - wyłącznie rosyjskojęzyczną - oparł na wspominanych już wielokrotnie niezwykle wartościowych źródłach ikonograficznych, mia-

34 Dotychczasowy stan wiedzy ukraińskiej historiografii na ten temat zawarty jest chociażby w pracy: I. Т. Муковський, О. Є. Лисенко, Звитяга і жертовність. Украӥнці на фронтах другої світової війни, Київ 1997.

35 А. Сова, Документи ЦДІА Украӥни у Львові про участь Дмитра Грицая в українському товаристві „Сокіл”, „Цитаделя. Львівський Мілітарний Альманах” 2011, частина 2 (6), s. 55-60.

36 Zob. choćby R. Potocki, Polityka państwa polskiego wobec zagrożenia ukraińskiego w latach 1930-1939, Lublin 2003.

${ }^{37}$ Szerzej o dziejach tej formacji zob. także: Ж. Горохов, Русская императорская гвардия, Москва 2006; Российская императорская гвардия, Коллегиальная работа, Москва-Санкт-Петербург 2005; О. Г. Гончаренко, Три века императорской гвардии, Москва 2006; Р. Ф. Незвецкий, Лейб-Гвардия императорской России, Москва 2009; B. Gembarzewski, Wojsko Polskie Królestwo Polskie 1815-1830, Warszawa 1903. 
nowicie na obrazach olejnych Józefata Łukaszewicza znajdujących się w zbiorach Lwowskiego Muzeum Historycznego ${ }^{38}$.

Tekst ten z pewnością może zainteresować potencjalnych polskich czytelników, głównie zaś historyków, którzy zajmują się kwestiami szeroko rozumianej „broni i barwy”. Pewnym zaskoczeniem może być jednak informacja o tym, iż jakoby wielki książę Konstanty Pawłowicz „,nie lubił nosić munduru generalskiego Królestwa Polskiego [i] na co dzień nosił wicemundur Podolskiego Pułku Kirasjerów"39. W zdaniu tym pojawiły się bowiem dwie nieścisłości. Po pierwsze, wielki książę nie mógł nosić żadnego munduru generalskiego Królestwa Polskiego, gdyż takowy nie istniał. Zgodnie z obowiązującymi ściśle określonymi i przestrzeganymi przepisami dotyczącymi ubioru ${ }^{40}$ nosił mundur generalski Wojska Polskiego. Ponadto, jak to wskazuje przechowywana w Polsce i pochodząca z epoki ikonografia oraz rozliczne świadectwa pamiętnikarzy, mały bądź wielki polski mundur generalski nosił, i to na dodatek codziennie, w czasie pełnienia służby, zaś jego rzeczywisty ani też manifestowany publicznie stosunek do Polaków i ich armii nie miał tutaj nic do rzeczy. Natomiast wicemundur Podolskiego Pułku Kirasjerów Lejb Gwardii zakładał poza służbą, $\mathrm{z}$ reguły w Belwederze, co w armii rosyjskiej podobnie jak w wielu innych armiach europejskich, było prerogatywą wynikającą z faktu, iż od 1818 r. był jego szefem rzeczywistym ${ }^{41}$. Wówczas często ubierał surdut

38 М. Слободянюк, Лейб-Гвардї Подільський Кірасирський Полк у живописі Юзефата Лукашевича зі збірки Львівського Історичного Музею, „Цитаделя. Львівський Мілітарний Альманах” 2011, частина 2 (6), s. 61-79.

39 Ibidem, s. 63.

${ }^{40} \mathrm{O}$ kwestiach z tym związanych oraz o stosunku wielkiego księcia Konstantego Pawłowicza do problemu przestrzegania w Wojsku Polskim z lat 1815-1830 przepisów dotyczących ubioru szerzej zob. chociażby: J. Kolańczyk, Dyscyplina mundurowa w armii Królestwa Polskiego, „Arsenał Poznański” 1998, R. VII, nr 1 (23); M. Trąbski, Armia wielkiego księcia Konstantego. Wyszkolenie i dyscyplina Wojska Polskiego w latach 1815-1830, Oświęcim 2013.

${ }^{41}$ Szerzej na temat genezy i dziejów europejskiej, w tym także polskiej, tradycji szefostw wojskowych zob.: A. Smoliński, Europejskie i polskie tradycje szefostw wojskowych XVI-XX wieku. Część 1, „Pro Memoria”. Pismo miłośników przeszłości” 2004, nr 2 (11); idem, Europejskie i polskie tradycje szefostw wojskowych XVI-XX wieku. Czesść 2, „Pro Memoria”. Pismo miłośników przeszłości” 2004, nr 3 (12); idem, Szef czy patron - tradycja i współczesność w Wojsku Polskim, [w:] Od armii komputowej do narodowej, red. M. Krotofil, A. Smoliński, t. 2: Dzieje militarne Polski i jej wschodnich sasiadów od XVI do XX wieku, Toruń 2005; idem, Szefostwa w Wojsku Polskim w latach 1919-1939 oraz ich związek z polska i europejska tradycją wojskowa, ,Pro Memoria. Pismo miłośników przeszłości” 2008, nr 1 (18). 
z barwami swego szefowskiego pułku ${ }^{42}$ i z generalskimi oznakami wodza naczelnego Wojska Polskiego ${ }^{43}$. Poza tym w dzień święta pułkowego lub też podczas innych uroczystości tego typu mógł też zakładać pełny - galowy mundur swego pułku, nadal jednak ze wspomnianymi właściwymi dla siebie oznakami stopnia ${ }^{44}$.

Ten sam autor przygotował również tekst zamieszczony w dziale „Wojskowa symbolika”. Dotyczy on pierwszych, wprowadzonych w latach 90. XX w. oznak oddziałów i okrętów noszonych na rękawach w Morskich Siłach Zbrojnych Ukrainy (Військово-Морські Сили України) ${ }^{45}$. Omówił on niełatwą historię ich powstania oraz symbolikę zawartą na oznakach tego typu. Warto zauważyć, że w ich wprowadzeniu do ukraińskiej floty sporą rolę odegrali służący w jej szeregach oficerowie, którzy dążyli do posiadania nowej symboliki wojskowej opartej na rodzimych ukraińskich elementach. Tekst ten jest bogato ilustrowany barwnymi wizerunkami omawianych przez autora oznak.

W niewystępującym wcześniej dziale „Propaganda wojenna” znalazł się również bogato ilustrowany i ciekawy także dla potencjalnego polskiego czytelnika tekst Jurija Łysego dotyczący plakatów propagandowych z okresu „wojny polsko-sowieckiej z 1920 r." ${ }^{\text {"6 }}$ znajdujących się obecnie w kolekcji Biblioteki Naukowej Lwowskiego Uniwersytetu Narodowego im. Iwana Franki we Lwowie ${ }^{47}$. Jego autor słusznie zauważył, iż w 1920 r. przeciwko Sowietom obok Wojska Polskiego walczył także jego ówczesny ukraiński sojusznik, mianowicie Armia Czynna Ukraińskiej Republiki Ludowej. Poza tym stwierdził też, że źródła ikonograficzne w postaci plakatów propagandowych i pocztówek odgrywają ogromną rolę w badaniach dotyczących historii XX w., w tym również wojny polsko-sowieckiej. Z poglądem tym wypada się zgodzić w całej rozciągłości, podobnie jak z tym,

42 Warto też tutaj pamiętać, iż nie był to jedyny pułk armii carskiej, którego szefem był wielki książę Konstanty Pawłowicz.

${ }^{43}$ Rocznik Woyskowy Królestwa Polskiego na rok 1825, Warszawa 1825, s. 5.

${ }^{44}$ Według części źródeł mogły to być również oznaki stopnia pułkownika.

${ }^{45}$ М. Слободянюк, Перші нарукавні емблеми частин $і$ кораблів ВійськовоМорських Сил України, „Цитаделя. Львівський Мілітарний Альманах” 2011, частина 2 (6), s. 80-83.

46 Jest to błędne sformułowanie, gdyż wojna polsko-sowiecka toczyła się w latach 1919-1920 , a wiosna i lato 1920 r. były tylko okresem jednej z jej kampanii. Niestety, poza autorami ukraińskimi, wzorem dawnej historiografii sowieckiej oraz współczesnej rosyjskiej, błąd ten często popełniają również autorzy polscy.

47 Ю. Лисий, Польсько-радянська війна 1920 року в колекиії плакатів Наукової Бібліотеки Львівського Національного Університету імені Івана Франка, „Цитаделя. Львівський Мілітарний Альманах" 2011, частина 2 (6), s. 84-108. 
iż w okresie tym plakat pełnił ważną funkcję w propagandzie zarówno sowieckiej $^{48}$, jak i polskiej ${ }^{49}$, a także ukraińskiej. W zbiorach wskazanej wcześniej biblioteki znajduje się w sumie 19 plakatów z tego okresu, z których 18 to plakaty polskie. Natomiast jeden został wydany przez Ukraińców. Biblioteka nie posiada natomiast żadnych ówczesnych plakatów sowieckich.

Wszystkie przedmioty tego typu zostały przez autora opisane wraz z podaniem - tam, gdzie to było możliwe - ich autora oraz miejsca wydania. Poza tym Jurij Łysyj skomentował również zawarte w nich treści propagandowe oraz odniesienia do ówczesnej sytuacji politycznej, a także do dość powszechnie rozumianych wówczas w Polsce kontekstów kulturowych. Warto też zauważyć, iż wszystkie te plakaty pochodzą z przedwojennych zbiorów Uniwersytetu Jana Kazimierza we Lwowie.

Tom 6 „Cytadeli” zamyka dość obszerne omówienie ukraińskojęzycznej wersji pracy zbiorowej pod redakcją Tadeusza Krząstka zatytułowanej Polska i Ukraina $w$ walce o niepodlegtość 1918-192050, które przygotował Ołeksander Diedyk ${ }^{51}$. Autor podkreślił wagę publikacji tego typu dla budowania dobrosąsiedzkich stosunków pomiędzy Polską a Ukrainą oraz wzajemnego poznawania historii obydwu narodów. Pomimo to, oceniając całą tę pracę, a także poszczególne zawarte w niej teksty, słusznie zauważył ich niedostatki. Warto też tutaj dodać, iż pewne zastrzeżenia do tej publikacji mają także polscy historycy, co powoduje, że cały szereg krytycznych uwag Ołeksandra Diedyka sformułowanych pod jej adresem należy uznać za słuszne ${ }^{52}$. Jest to jedyna pozycja w nowym dziale „Cytadeli” zatytułowanym: „Recenzje i krytyka”.

48 Szerzej zob. choćby: П. В. Суслов, Политическое обеспечение советско-польской кампании 1920 года, Москва-Ленинград 1930; T. Teslar, Propaganda bolszewicka podczas wojny polsko-rosyjskiej 1920 roku, Warszawa 1938; A. J. Leinwand, Czerwonym młotem w Orta Białego. Propaganda sowiecka w wojnie z Polska 1919-1920, Warszawa 2008.

49 Zob. choćby: Poland first to fight. The Catalogue of The Polish Military Poster, ed. A. Gąsiorowska, M. Lewnau, Warszawa 2002; Rok 1920. Wojna Polski z Rosja bolszewicka, wyb. i oprac. A. Knyt, Warszawa 2005; 1920. Wojna o Polske, wyb. i oprac. A. Knyt, Warszawa 2010.

${ }^{50}$ Zob. Polska i Ukraina w walce o niepodległość 1918-1920, red. T. Krząstka, Warszawa 2009. Natomiast jej ukraińskojęzyczna wersja to: Польща та Україна в боротбі за незалежність 1918-1920, під редакцією Т. Кшонстка, Варшава 2010.

51 О. Дєдик, Невиразне відлуння важкого братерства: рецензія на книгу ,Польщза та Україна в боротьбі за незалежність 1918-1920”, „Цитаделя. Львівський Мілітарний Альманах" 2011, частина 2 (6), s. 109-115.

${ }^{52}$ Zob. chociażby: E. Wiszka, Ostrożnie z tym wydaniem, „Przegląd Historyczno-Wojskowy” 2010, R.XI (LXII), nr 3 (232). 
Kończąc omawianie tego tomu „Cytadeli”, należy zauważyć, iż dla potencjalnego polskiego czytelnika najwartościowszym i jednocześnie najciekawszym zawartym w nim opracowaniem może okazać się tekst dotyczący polskich plakatów propagandowych z okresu wojny polsko-sowieckiej.

Kolejny 7, tym razem monotematyczny, tom „Cytadeli” ukazał się w 2012 r. ${ }^{53}$ Zawiera on tylko jeden obszerny tekst zamieszczony w dziale "Historia wojskowa”. Jest to thumaczenie sporego fragmentu przestarzałej już raczej pracy austriackiego historyka wojskowego Wilhelma Edlena von Geblera ${ }^{54}$ dotyczącego działań dowodzonego przez Karola Filipa von Schwarzenberga księcia Krumay Austriackiego Korpusu Posiłkowego, który w 1812 r., jako część Wielkiej Armii cesarza Napoleona I, walczył na Wołyniu z wojskami rosyjskimi ${ }^{55}$. W ten sposób, wykorzystując przypadającą wtenczas 200 rocznicę najazdu Napoleona na Rosję, jego tłumacz i redaktorzy ${ }^{56}$ zamierzali przybliżyć potencjalnemu ukraińskiemu czytelnikowi działania zbrojne wojny ojczyźnianej 1812 r., które wówczas miały miejsce na „Ukrainie” ${ }^{57}$. Jednocześnie chcieli też, aby odbiorca ukraiński

53 Liczy on 124 strony tekstu.

54 W. E. von Gebler, Das K.K. Österreichische Auxiliar Corps in russischen Feldzuge 1812, Vien 1863.

55 „Ми боремося разом із ними, але не за них. Ми боремося са себе”: Дії корпусу князя Карла Швариенберга на території Украӥни під час Російського походу Наполеона у версї̈ Вільгельма Едлєна фон Геблєра, переклад К. Поліщук, „Цитаделя. Львівський Мілітарний Альманах" 2012, частина 1 (7), s. 5-122.

56 Są to: Mychajło Słobodianiuk, Jurij Mocznikow i Oleg Fieszowiec.

57 Zauważyć tutaj należy, iż po upadku Rzeczypospolitej Obojga Narodów pojęcie „Ukraina” na długi czas praktycznie przestało istnieć. Dla Rosjan bowiem już wcześniej Lewobrzeże było „Małorosją” podzieloną następnie (w XVIII w.) na gubernie czernichowską i połtawską. Zaś pozostałe ziemie dzisiejszej Ukrainy stały się przede wszystkim guberniami wołyńską i podolską, które powstały po podziale Rzeczypospolitej na jej ziemiach wchłoniętych w końcu XVIII w. przez imperium carskie - szerzej zob. chociażby: Słownik geograficzny Królestwa Polskiego i innych krajów słowiańskich, red. B. Chlebowski, W. Walewski, t. 8, Warszawa 1887, s. 442; Słownik geograficzny Królestwa Polskiego i innych krajów słowiańskich, red. B. Chlebowski, t. 12, Warszawa 1892, s. 778-779; Stownik geograficzny Królestwa Polskiego i innych krajów słowiańskich, red. B. Chlebowski, t. 13, Warszawa 1893, s. 931; Українське козацтво. Малая енциклопедія. Керівник авторського колективу Ф. Г. Турченко, Київ-Запоріжжя 2006, s. 361; Б. Сушинський, Всесвітна козацька енииклопедія XV - початку XXI століть, Одеса 2007, s. 257-258; Казачество. Эициклопедия. Колегальная работа - главный редактор А. П. Федотов, Москва 2008, s. 358. Termin ten należy więc rozumieć jako obszar współczesnego, niepodległego państwa ukraińskiego. O motywach takiego postępowania redakcji tego periodyku zob.: A. Smoliński, „Cytadela”- nowy ukraiński periodyk poświęcony historii wojskowej. Omówienie tomów od 1 do 4 za lata 2009-2010, „Europa Orientalis. Studia z dziejów Europy Wschodniej i państw bałtyckich” 2013, t. 4, s. 159. 
mógł poznać także inną niż dawniejsza sowiecka ${ }^{58}$ bądź też współczesna rosyjska ${ }^{59}$ wersję historii tych zmagań. Poza tym, co podkreślili redaktorzy, zarówno w szeregach armii carskiej, jak i w licznych regimentach austriackich służyło wtenczas sporo późniejszych Ukraińców. Cały ten tekst zaopatrzony został przez tłumaczy w liczne przypisy, w których przybliżono sylwetki występujących w nim osób, a także w odpowiednie schematy i materiał ilustracyjny.

Przedstawia on następujące zagadnienia: skład i strukturę organizacyjną Austriackiego Korpusu Posiłkowego w 1812 r.; wymarsz ze Lwowa i wejście Korpusu na terytorium Księstwa Warszawskiego; stosunek sił walczących stron w początkowym okresie kampanii 1812 r.; przejście Austriackiego Korpusu Posiłkowego przez Bug; pierwsze walki z Rosjanami; początkowe operacje rosyjskiej armii Aleksandra Tormasowa na Wołyniu; porażkę Sasów pod Kobryniem; połączenie sił austriackich i saskich oraz ich wspólne działania ofensywne przeciw armii Tormasowa do linii rzeki Styr; walki na linii Styru; przybycie rosyjskiej Armii Dunajskiej admirała Czyczagowa nad Styr i przejęcie inicjatywy przez Rosjan; przejście sił austriackich i saskich na drugi brzeg Bugu. Całość tego tłumaczenia kończy posłowie przygotowane przez redaktorów ${ }^{60}$.

Dla potencjalnego polskiego czytelnika, który w odniesieniu do wydarzeń kampanii rosyjskiej $1812 \mathrm{r}$. dysponuje wartościową i nadal aktualną literaturą naukową lub popularnonaukową w języku polskim ${ }^{61}$, opracowanie to, choć skądinąd ciekawe, nie przedstawia większej wartości, tym bardziej że w Polsce możliwy jest także dostęp do pełnej wersji monografii austriackiego feldmarszałka leutnanta Geblera.

Kończąc to krótkie omówienie kolejnych trzech tomów „Cytadel” po raz kolejny należy stwierdzić, że choć nie wszystkie teksty zamieszczone na jej łamach w 2011 i 2012 r. mają stricte naukowy charakter i nie wszystkie cechuje dostateczny naukowy obiektywizm, to jednak warto zajrzeć do tego ukraińskiego periodyku historyczno-wojskowego. Można tam bo-

58 Zob. П. А. Жилин, Гибель наполеоновской армии в России, Москва 1974.

59 Zob.: Отечественна война 1812 года. Эничиклопедия, коллегиальная работа главный редактор В. М. Безотосный, Москва 2004; А. И. МихайловскийДанилевский, Описание Отечественной войны в 1812 году, Москва 2008 (pierwsze wydanie tej pracy ukazało się już za panowania cara Mikołaja I).

${ }^{60}$ М. Слободянюк, Ю. Мочніков, О. Фешовець, Післяслово, „Цитаделя. Львівський Мілітарний Альманах" 2012, частина 1 (7), s. 80.

61 Spośród licznych prac warto tutaj wymienić chociażby: M. Kukiel, Wojna 1812 roku, t. 1-2, Warszawa 1937; A. Zamoyski, 1812. Wojna z Rosja, przeł. M. Ronikier, Kraków 2007. 
wiem znaleźć również ustalenia, które mogą stanowić uzupełnienie naszej dotychczasowej wiedzy historycznej, głównie zaś tej z zakresu niełatwej i nadal pełnej koniecznych do rozwikłania tajemnic i sprzeczności wspólnej polsko-ukraińskiej przeszłości, tym bardziej że postęp w tych badaniach następuje dość powoli i nadal obarczony jest wieloma stereotypami.

Aleksander Smoliński 